\title{
Potensi Pelanggan Tunggakan PDAM Menggunakan Metode K-Medoids dengan Optimasi Ant Colony Optimization (ACO)
}

\author{
Hardiyusa $^{1}$, Made Sudarma ${ }^{2}$, Nyoman Pramaita ${ }^{3}$
}

\begin{abstract}
PDAM in carrying out operational activities is greatly influenced by the receivables or arrears of customer water bills. Some factors that influence customer patterns in delinquent water bills are customer class and consumption of water usage, which affects the water bill paid by the customer. This study will apply the K-Medoids clustering method to find out customers who are delinquent in the PDAM by optimizing the selection of cluster centers using the Ant Colony Optimization (ACO) algorithm. In this study the combination of ACO and K-Medoids methods is called ACOMedoids. The results with the ACOMedoids method can produce a high level of accuracy from the comparison of clustering data with actual bill data. This can be seen from the results of accuracy which is always better than the K-Medoids method, which is the highest achieves $\mathbf{9 7 . 6 5 \%}$ accuracy for ACOMedoids while K-Medoids is $\mathbf{8 8 . 2 9 \%}$. Accuracy results show that the ACO algorithm can produce optimal cluster center points in the clustering process of the K-Medoids method.
\end{abstract}

Intisari-PDAM dalam menjalankan kegiatan operasional sangat dipengaruhi oleh piutang atau tunggakan tagihan air pelanggan. Beberapa faktor yang mempengaruhi pola pelanggan dalam menunggak tagihan air yaitu golongan pelanggan dan konsumsi pemakaian air sehingga mempengaruhi tagihan air yang dibayar oleh pelanggan. Penelitian ini akan diterapkan metode clustering $\mathrm{K}$-Medoids untuk mengetahui pelanggan yang menunggak di PDAM dengan melakukan optimasi pada pemilihan titik pusat cluster menggunakan algoritma Ant Colony Optimization (ACO). Dalam penelitian ini penggabungan metode ACO dan $K$-Medoids disebut ACOMedoids. Hasil dengan metode ACOMedoids dapat menghasilkan tingkat akurasi yang tinggi dari perbandingan data hasil clustering dengan data tagihan aktual. Hal ini terlihat pada hasil akurasi yang selalu lebih baik dibandingkan dengan metode $K$-Medoids yaitu tertinggi mencapai akurasi $97,65 \%$ untuk ACOMedoids sedangkan $K$ Medoids $\mathbf{8 8 , 2 9 \%}$. Hasil akurasi menunjukkan algortima ACO dapat menghasilkan titik pusat cluster yang optimal pada proses clustering metode $\mathrm{K}$-Medoids.

Kata Kunci-PDAM, Tunggakan, Clustering, K-Medoids, ACO, ACOMedoids.

\section{Pendahuluan}

Perusahaan Daerah Air Minum (PDAM) merupakan badan usaha milik daerah yang dibentuk oleh Pemerintah Daerah

\footnotetext{
${ }^{1}$ Mahasiswa Magister Teknik Elektro Fakultas Teknik Universitas udayana Jalan Kampus Bukit Jimbaran 80361 INDONESIA telp: 0361-703315; fax: 0361-703315 e-mail: hardiyusa.bss@gmail.com

${ }^{2,3}$ Dosen Jurusan Teknik Elektror Fakultas Teknik Universitas Udayana, Jalan Kampus Bukit Jimbaran 80361 INDONESIA telp: 0361-703315; fax: 0361-703315; e-mail: msudarma@unud.ac.id, n_pramaita@yahoo.com

raruıusa: rotensı reıanggan ı unggakan rVAııı ...
}

Provinsi, Kabupaten dan atau Kota yang bergerak di bidang pelayanan air minum [1]. Dalam pengelolaannya, PDAM mengalami kendala dan hambatan dalam melakukan kegiatan operasional di antaranya, seperti keterbatasan jumlah SDM dan kompetensi, efektivitas penagihan, efektivitas produksi, kehilangan air, jumlah tunggakan pelanggan yang besar dan lain-lain yang menimbulkan kerugian bagi PDAM [1]. Besarnya piutang yang tidak dapat di tagihkan akan mempengaruhi kelancaran operasional suatu PDAM, sehingga berdampak kepada pelanggan PDAM yang tidak mendapatkan pelayanan secara maksimal. Beberapa faktor yang mempengaruhi pola pelanggan dalam menunggak tagihan air adalah golongan dari pelanggan dan konsumsi pemakaian air sehingga mempengaruhi tagihan air yang dibayar oleh pelanggan. Pemanfaatan faktor tersebut dapat digunakan untuk proses pengelompokan pelanggan sesuai dengan polanya masing-masing, sehingga dapat diketahui potensi pelanggan yang akan menunggak.

Segmentasi atau pengelompokan pelanggan pada suatu perusahaan dapat membantu perusahaan tersebut dalam membuat keputusan terhadap kelompok pelanggan tertentu sesuai kebijakan suatu perusahaan. Beberapa penelitian mengenai analisis pelanggan antara lain penelitian mengenai pengelompokan pelanggan berdasarkan pola komsumsi pemakaian air terhadap kebutuhan air perkotaan menggunakan metode clustering Kohonen atau Self Organized Maps (SOM) [2]. Penelitian tersebut menghasilkan kelompok data pelanggan terhadap pola komsumsi air untuk kategori rumah tangga dan non-perusahaan. Hasil cluster digunakan dalam optimalisasi pengelompokan pada pelanggan baru berdasarkan pada kriteria atau faktor yang telah ditentukan. Penelitian berikutnya mengenai segmentasi dan klasifikasi perilaku pembayaran nasabah pada perusahaan penyedia jasa multimedia dengan algoritma $K$-Means dan C4.5 [3]. Dalam penelitian tersebut tingkat potensi nasabah juga bisa menjadi acuan dalam promosi, retensi, dan pencegahan pelanggan menunggak. Penelitian selanjutnya mengenai analisa dalam memprediksi pelanggan apakah mereka akan meninggalkan perusahaan atau tidak, penelitian tersebut di lakukan pada industri telekomunikasi [4] dengan membandingkan metode decision tree J-48 dengan teknik regresi logistik. Penelitian tersebut digunakan untuk mencari potensi pelanggan yang berhenti berlangganan (churn), sehingga dapat menghindari kerugian yang lebih besar di alami oleh perusahaan. Penelitian berikutnya yaitu mengembangkan model prediksi risiko pinjaman pada bank dengan menggunakan data mining [5]. Tiga algoritma klasifikasi yang digunakan yaitu $J-48$, bayesNet dan naiveBayes. Hasil dari penelitian tersebut adalah prediksi nasabah bank itu baik atau tidak dalam melakukan pinjaman.

p-ISSN:1693 - 2951; e-ISSN: 2503-2372 
Berdasarkan beberapa penelitian mengenai potensi pelanggan, serta memperhitungkan aspek keuangan dalam hal efektivitas penagihan PDAM, maka dikembangkan sebuah ide untuk melakukan penelitian mengenai potensi pelanggan tunggakan pada PDAM dengan menggunakan metode clustering K-Medoids. Dalam implementasinya K-Medoids memang lebih baik dibandingkan $K$-Means, tetapi metode ini memiliki kelemahan yaitu kompleksitas komputasinya yang tinggi sehingga berdampak pada performa proses clustering secara keseluruhan. Selain itu, proses pemilihan pusat cluster awal secara acak membuat hasil dari proses clustering menjadi tidak stabil, sehingga $K$-Medoids juga belum dapat mengatasi masalah lokal optimal. Oleh karena itu diperlukan suatu algoritma optimasi yang dapat meningkatkan performa serta mengatasi kelemahan yang ada pada metode $K$-Medoids tradisional.

Beberapa penelitian mengenai optimasi metode clustering antara lain penelitian mengenai pengelompokan (clustering) data dengan teknik $k$-medoids yang digabungkan dengan algoritma Bat (kelelawar) [6]. Algoritma Bat digunakan untuk efisiensi dalam menentukan titik pusat cluster yang lebih baik. Penggabungan kedua metode tersebut dapat menghasilkan pengelompokan analisis data yang lebih baik. Penelitian berikut mengenai penentuan kompetensi mahasiswa dengan algoritma genetika dan metode Fuzzy C-Means [7]. Hasil percobaan yang dilakukan, penggabungan Algoritma Genetik dan Fuzzy C-Means memberikan hasil yang lebih baik dibandingkan Fuzzy $C$ - Means saja dengan persentase ratarata kesesuaian pada pengujian yang dilakukan adalah sebesar $88.89 \%$. Penelitian selanjutnya mengenai optimasi pusat cluster K-Prototype dengan algoritma genetika [8]. Dari beberapa hasil percobaan yang dilakukan metode $K$-Prototype dengan Algortima Genetika menghasilkan hasil yang terbaik dari metode K-Prototype tanpa Algoritma Genetika dan metode $K$-Means.

Berdasarkan latar belakang tersebut, maka dalam penelitian ini diperlukan suatu algoritma optimasi yang dapat meningkatkan performa serta mengatasi kelemahan yang ada pada metode $\mathrm{K}$-Medoids tradisional. Ant Colony Optimization (ACO) merupakan suatu algoritma yang didasarkan oleh pola semut di dalam membentuk suatu koloni dan mencari makanan [9]. Algortima ACO akan digunakan untuk optimasi pada pemilihan titik pusat cluster sebelum dilakukan proses clustering $\mathrm{K}$-Medoids. Penggabungan metode clustering dan algoritma ACO dalam penelitian ini disebut ACOMedoids. Berdasarkan hasil clustering penelitian ini dihitung nilai akurasi dengan menggunakan metode confusion matrix.

\section{Algoritma dan Metode Pengujian}

\section{A. K-Medoids}

Strategi dasar dari algoritma clustering K-Medoids adalah untuk menemukan $\mathrm{k}$ cluster dalam $\mathrm{n}$ objek dengan pertama kali secara arbitrarily menemukan wakil dari objek (medoid) untuk tiap-tiap cluster [10]. Masing-masing sisa objek di cluster dengan medoids ke yang paling mirip. Strategi ini kemudian secara iteratif menggantikan satu medoids dari yang non medoids sepanjang kualitas dari hasil clustering ditingkatkan. PAM (partition around medoids) adalah jenis $K$ Medoids algoritma clustering. Pada PAM ditemukan k cluster di objek $\mathrm{n}$ dengan terlebih dahulu mencari benda perwakilan (medoid) untuk setiap cluster. Set awal medoids dapat dipilih sesuai keinginan. Kemudian proses iteratif menggantikan salah satu medoids oleh salah satu non-medoids lainnya selama total jarak pengelompokan yang dihasilkan mengalami peningkatan.

\section{B. Ant Colony Optimization (ACO)}

Ant Colony Optimization (ACO) termasuk dalam kelompok swarm intelligence, yang merupakan salah satu jenis pengembangan paradigma yang digunakan untuk menyelesaikan masalah optimasi dimana inspirasi yang digunakan untuk memecahkan masalah tersebut berasal dari perilaku kumpulan atau kawanan (swarm) serangga [11]. Antbased techniques pertama kali digunakan oleh Marco Dorigo dan Luca Maria Gambardella dengan menggunakan ACO untuk menyelesaikan Traveling Salesman Problem (TSP) [9].
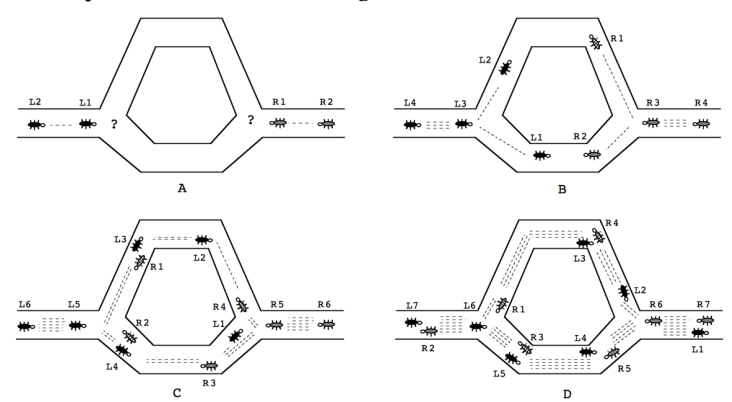

Gambar 1: Koloni semut mencari makan [9]

Algoritma Ant Colony Optimation berdasarkan pada tingkah laku semut dalam mencari makanan. Semut, dalam perjalanan mencari makanan, akan mengeluarkan aroma kimia yang dikenal sebagai feromon. Feromon yang dikeluarkan berfungsi sebagai jejak untuk semut lainnya agar dapat menemukan sumber makanan yang sudah ditemukan oleh semut sebelumnya dan setiap semut akan meninggalkan feromon sebagai jejak juga untuk dirinya dan semut lainnya. Semut yang melewati jalur terpendek dan terdekat akan meninggalkan feromon yang lebih kuat untuk dicium oleh semut lainnya. Semut lainnya, secara alami akan mengikuti jejak feromon yang terkuat atau terpendek. Berikut adalah langkah-langkah semut dalam mencari makanan:

1. Semut-semut akan mencari sumber makanan secara acak melalui jalur yang memungkinkan.

2. Saat menemukan makanan mereka kembali ke sarangnya dengan memberikan tanda dengan jejak feromon.

3. Semut-semut yang lain tidak akan mencari makanan secara acak kembali melainkan akan mengikuti atau mengambil jalur dengan feromon terkuat.

4. Akhirnya semut akan mengambil jalur terpendek, di mana jalur lainnya akan semakin kehilangan feromon yang telah menguap.

\section{Pengujian Confusion Matrix}

Proses pengujian dilakukan dengan metode confusion matrix. Confusion matrix adalah suatu metode yang digunakan 
untuk melakukan perhitungan akurasi pada konsep data mining [12]. Proses pengujian dengan confusion matrix dilakukan pada hasil metode clustering $K$-Medoids tanpa menggunakan algoritma optimasi dan hasil metode clustering K-Medoids dengan menggunakan algoritma optimasi ACO.

TABEL I

Model Confusion MATRIX POTENSI PELANGGAN TUNGGAKAN

\begin{tabular}{|c|c|c|c|}
\hline \multirow{2}{*}{\multicolumn{2}{|c|}{ Kelas }} & \multicolumn{2}{|c|}{ Hasil Klasifikasi } \\
\hline & & \multirow{2}{*}{$\begin{array}{c}\text { Menunggak } \\
\text { True Positive } \\
\text { (TP) }\end{array}$} & \multirow{2}{*}{$\begin{array}{c}\text { Lancar } \\
\text { False Negatives } \\
\text { (FN) }\end{array}$} \\
\hline Hasil & Menunggak & & \\
\hline Aktual & Lancar & $\begin{array}{c}\text { False Positives } \\
\text { (FP) }\end{array}$ & $\begin{array}{c}\text { True Negatives } \\
\text { (TN) }\end{array}$ \\
\hline
\end{tabular}

$\mathrm{TP}=$ Jumlah data jika hasil klasifikasi dari sistem menunggak (positif) dan jika hasil aktual juga menunggak (positif).

$\mathrm{FG}=$ Jumlah data jika hasil klasifikasi dari sistem lancar (negatif) dan jika hasil aktual menunggak (positif).

$\mathrm{FP}=$ Jumlah data jika hasil klasifikasi dari sistem menunggak (positif) dan jika hasil aktual juga lancar (negatif).

$\mathrm{TN}=$ Jumlah data jika hasil klasifikasi dari sistem lancar (negatif) dan jika hasil aktual juga lancar (negatif).

Pengujian dengan confusion matrix berdasarkan tabel di atas, nilai dari TP, FN, FP dan TN dapat menghasilkan nilai akurasi. Nilai akurasi adalah persentase ketepatan record data yang diklasifikasikan secara benar setelah dilakukan pengujian pada hasil klasifikasi. Dengan kata lain, nilai akurasi merupakan perbandingan antara data yang terklasifikasi benar dengan keseluruhan data.

$$
\text { Akurasi }=\frac{T P+T N}{T P+T N+F P+F N} \times 100 \%
$$

\section{PROSES DATA MINING}

Sistem yang akan dikembangkan dalam penelitian ini adalah penerapan data mining untuk mengetahui potensi pelanggan tunggakan PDAM dengan metode clustering yaitu $K$-Medoids yang akan di optimasi dalam pencarian titik pusat cluster dengan algoritma ACO. Sistem yang akan dikembangkan terdiri dari dua proses utama yaitu proses data preparation dan proses data mining. Gambar 2 menunjukkan gambaran umum dari sistem yang akan dikembangkan.

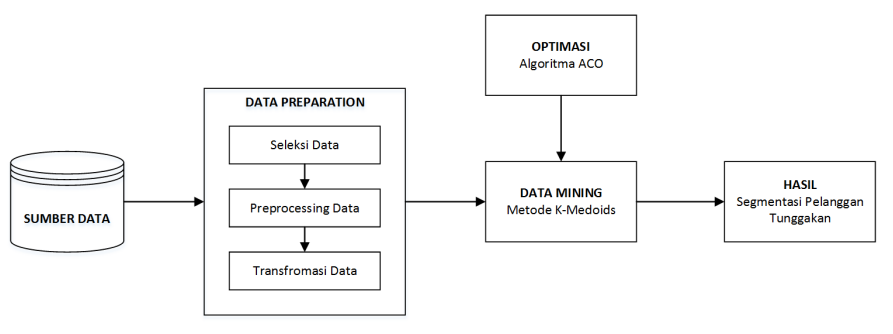

Gambar 2: Gambaran umum sistem
Sumber data dalam penelitian ini merupakan data tagihan pelanggan PDAM yang berasal dari database sistem billing PDAM milik PT. Bima Sakti Sanjaya. PT. Bima Sakti Sanjaya adalah perusahaan yang menjadi mitra PDAM dalam hal sistem informasi manajemen yang bertempat di A. Yani Utara Peguyangan, Denpasar, Bali. PDAM yang digunakan dalam penelitian ini sebanyak 6 PDAM dengan periode tagihan adalah 3 tahun yaitu dari periode Agustus 2014 sampai dengan periode Agustus 2017.

\section{B. Data preparation}

Sumber data yang telah didapatkan selanjutnya akan diolah menjadi dataset akhir atau data yang akan digunakan dalam proses pada tahap data mining. Pada tahapan ini mencakup pemilihan tabel, record, serta atribut-atribut data, termasuk di dalamnya proses pembersihan dan transformasi data untuk kemudian dijadikan masukan dalam tahap data mining. Tahap ini dapat diulang beberapa kali untuk mendapatkan hasil yang lebih baik sesuai dengan kebutuhan. Proses data preparation terdiri dari 3 tahap, yaitu tahap seleksi data, tahap preprocessing data dan transformasi data.

1. Proses seleksi data dilakukan dengan cara memilih atributatribut pada tabel tersebut yang diperlukan saat proses data mining, yaitu atribut periode, nosamb, nama, tarif, pakai, total, dan flaglunas.

2. Preprocessing dilakukan proses pembersihan (data cleansing) sehingga mendapatkan data tanpa adanya data noise dan missing value, yaitu atribut pakai dan total tidak diperbolehkan bernilai 0 .

3. Transformasi data, dalam penelitian ini akan di gunakan tipe titik 3 dimensi sehingga atribut-atribut yang akan digunakan akan disesuaikan kembali menjadi atribut pakai, tarif dan total.

Jumlah hasil data preparation untuk masing-masing PDAM dapat dilihat pada Tabel II.

TABEL II

JUMLAH HASIL DATA PREPARATION MASING-MASING PDAM

\begin{tabular}{|c|l|c|c|c|}
\hline No & Nama PDAM & Pelanggan & $\begin{array}{c}\text { Data } \\
\text { Rekening }\end{array}$ & $\begin{array}{c}\text { Data } \\
\text { Preparation }\end{array}$ \\
\hline 1 & $\begin{array}{l}\text { PDAM Kab. } \\
\text { Timor Tengah } \\
\text { Utara }\end{array}$ & 4.025 & 70.781 & 44.698 \\
\hline 2 & $\begin{array}{l}\text { PDAM Kab. } \\
\text { Buru }\end{array}$ & 4.099 & 46.025 & 34.581 \\
\hline 3 & $\begin{array}{l}\text { PDAM Kota } \\
\text { Pekanbaru }\end{array}$ & 12.309 & 193.846 & 88.340 \\
\hline 4 & $\begin{array}{l}\text { PDAM Kab. } \\
\text { Polewali } \\
\text { Mandar }\end{array}$ & 15.912 & 471.353 & 391.342 \\
\hline 5 & $\begin{array}{l}\text { PDAM Kab. } \\
\text { Klungkung }\end{array}$ & 29.919 & 807.442 & 763.100 \\
\hline 6 & $\begin{array}{l}\text { PDAM Kota } \\
\text { Tangerang }\end{array}$ & 44.389 & 1.083 .695 & 896.368 \\
\hline
\end{tabular}

A. Sumber Data 


\section{Metode K-Medoids}

Teknik data mining yang digunakan dalam penelitian ini adalah clustering dengan metode $K$-Medoids. Pada tahap ini data yang telah disiapkan pada tahap sebelumnya data preparation dilakukan pengolahan untuk mendapatkan beberapa kelompok data (cluster). Gambar 3 menunjukkan bagan alir dari proses data mining dengan metode $K$-Medoids

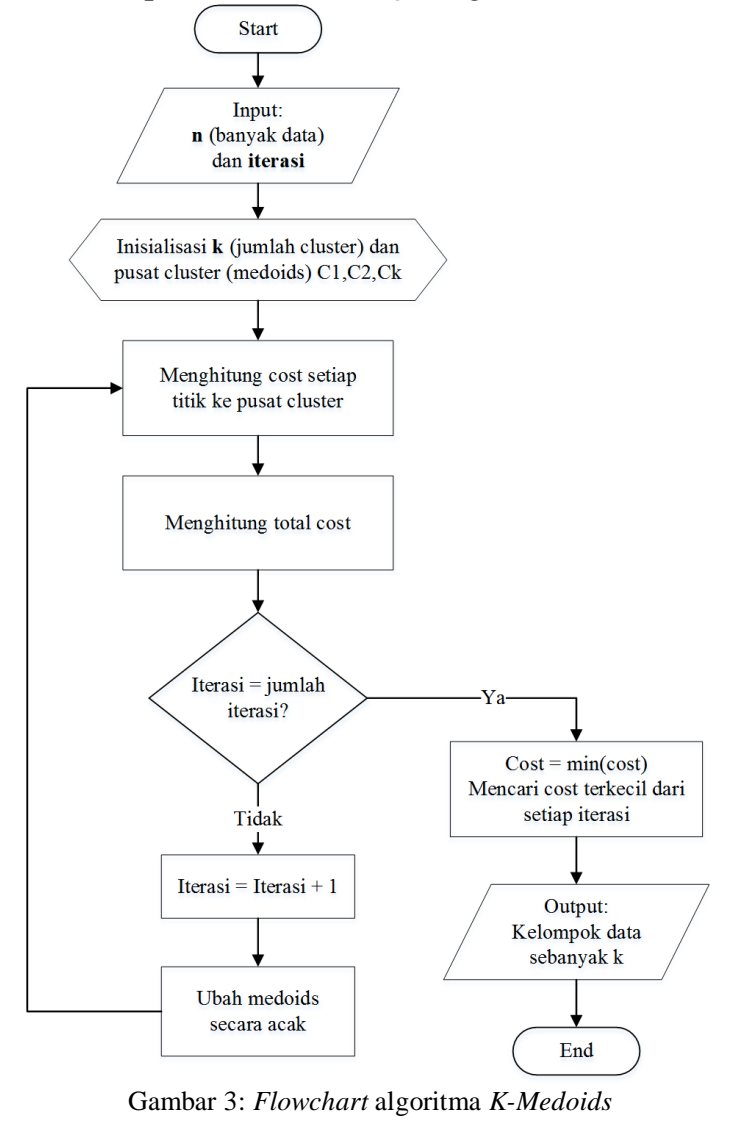

Pembentukan kelompok data pelanggan sesuai dengan tahapan seperti pada flowchart metode K-Medoids diatas dapat dijelaskan sebagai berikut:

1. Masukkan jumlah data $n$ yang akan di proses dan jumlah iterasi yang akan dilakukan.

2. Menentukan jumlah cluster k dan pusat cluster (medoids) untuk masing-masing cluster dari inputan data $\mathrm{n}$.

3. Menghitung cost setiap titik data ke pusat cluster (medoids) menggunakan rumus Minkowski.

4. Menghitung total cost dari cluster yang sudah terbentuk

5. Mengecek iterasi yang telah dilakukan sama dengan jumlah iterasi yang telah ditentukan.

6. Jika ya pilih nilai total cost yang terkecil dari total cost yang telah dilakukan selama iterasi. Data hasil cluster dengan total cost yang terkecil tersebut akan menjadi kelompok data yang akan digunakan untuk proses selanjutnya.

7. Jika tidak tambahkan iterasi dan ubah medoids secara acak.

8. Ulangi langkah 3 sampai 8 sampai tidak ada perubahan dalam medoids tersebut.
D. Optimasi Titik Cluster K-Medoids dengan ACO

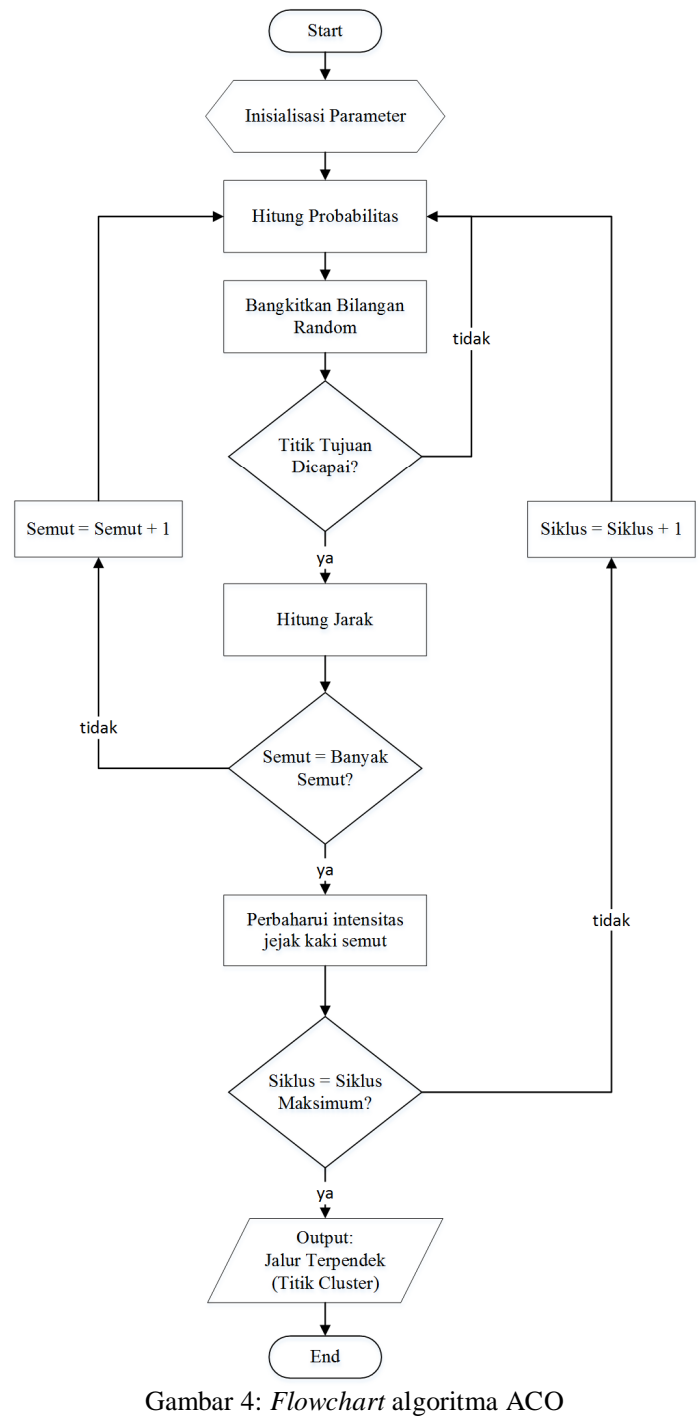

Pada tahap ini data hasil data preparation dilakukan pencarian titik cluster sebelum tahap clustering K-Medoids dilakukan. Gambar 4 menunjukkan bagan alir dari proses algoritma ACO.

\section{HASIL DAN PEMBAHASAN}

\section{A. Proses Data mining}

Pembentukan cluster data pelanggan dengan menggunakan metode $K$-Medoids pada penelitian ini terdiri dari beberapa parameter yaitu jumlah data yang digunakan sesuai dengan jumlah data hasil data preparation, jumlah iterasi yaitu 10 kali, jumlah cluster yaitu 2 cluster (menunggak dan lancar), perhitungan jarak antar titik dengan rumus Minkowski. Hasil proses data mining dengan menggunakan metode $\mathrm{K}$-Medoids dapat dilihat pada Tabel IV.

Metode ACOMedoids adalah metode penggabungan antara algoritma ACO yang digunakan untuk membentuk atau menentukan pusat cluster dengan metode $K$-Medoids dalam pembentukan clustering berdasarkan pusat cluster tersebut. 
Majalah Ilmiah Teknologi Elektro, Vol. 17, No. 3, September - Desember 2018

DOI: https://doi.org/10.24843/MITE.2018.v17i03.P08

Tahap pertama menentukan titik pusat cluster dengan algoritma ACO digunakan beberapa parameter yaitu jumlah iterasi sebanyak 3 kali, nilai $\alpha$ digunakan 1 , nilai $\beta$ adalah 1 , nilai rho $(\rho) 0.5$ dan jumlah semut yang digunakan adalah 3 .

Tahap kedua yaitu hasil pusat cluster dari hasil algortima ACO digunakan sebagai pusat cluster pada metode clustering K-Medoids untuk mendapatkan cluster sebagai data latih.

Proses pembentukan cluster data pelanggan pada metode $K$ Medoids digunakan beberapa parameter yaitu jumlah data yang digunakan sesuai dengan jumlah data hasil data preparation, jumlah iterasi yaitu 3 kali, jumlah cluster yaitu 2 cluster (menunggak dan lancar), perhitungan jarak antar titik dengan rumus Minkowski. Hasil proses data mining dengan menggunakan metode ACOMedoids terlihat pada Tabel IV.

TABEL IV

Hasil Proses Metode $K$-MEDOIDS DAN MEtode ACOMEDOIDS

\begin{tabular}{|c|l|c|c|c|c|c|c|}
\hline \multirow{2}{*}{ No } & \multicolumn{1}{|c|}{ Nama PDAM } & \multicolumn{3}{c|}{ K-Medoids } & \multicolumn{3}{c|}{ ACOMedoids } \\
\cline { 3 - 8 } & \multicolumn{1}{|c|}{$\begin{array}{c}\text { Waktu } \\
\text { detik) }\end{array}$} & Pusat Cluster 1 & Pusat Cluster 2 & $\begin{array}{l}\text { Waktu } \\
(\text { detik })\end{array}$ & Pusat Cluster 1 & Pusat Cluster 2 \\
\hline 1 & $\begin{array}{l}\text { PDAM Kab. Timor Tengah } \\
\text { Utara }\end{array}$ & 1,88 & $3400,1,37000$ & $2600,62,86200$ & 12,05 & $3400,20,30000$ & $1000,95,76000$ \\
\hline 2 & PDAM Kab. Buru & 1,43 & $1580,37,122218$ & $2080,79,135500$ & 13,00 & $1580,10,29400$ & $2080,59,77960$ \\
\hline 3 & PDAM Kota Pekanbaru & 3,70 & $7700,26,101100$ & $2800,70,99900$ & 19,70 & $2300,76,310600$ & $3500,57,74000$ \\
\hline 4 & $\begin{array}{l}\text { PDAM Kab. Polewali } \\
\text { Mandar }\end{array}$ & 16,38 & $15000,13,30300$ & $15500,54,77500$ & 21,21 & $15000,4,22500$ & $15500,66,88100$ \\
\hline 5 & PDAM Kab. Klungkung & 34,66 & $1400,29,82600$ & $1900,74,115600$ & 47,90 & $1400,29,82600$ & $1900,85,153000$ \\
\hline 6 & PDAM Kota Tangerang & 39,83 & $2775,27,126375$ & $3275,92,264125$ & 57,19 & $2775,5,17375$ & $3275,71,136875$ \\
\hline
\end{tabular}

\section{B. Hasil Pengujian}

Pengujian pada metode $K$-Medoids menggunakan datalatih hasil cluster pada proses data mining dengan metode $K$ Medoids sebelumnya. Data aktual (data transaksi pembayaran) yang digunakan dalam pengujian adalah periode tagihan September 2017 dengan transaksi pembayaran bulan Oktober 2017. Pengujian langsung menggunakan aplikasi dan terlihat pada Gambar 5 dan Tabel $\mathrm{V}$ menunjukkan hasil pengujian untuk masing-masing PDAM.

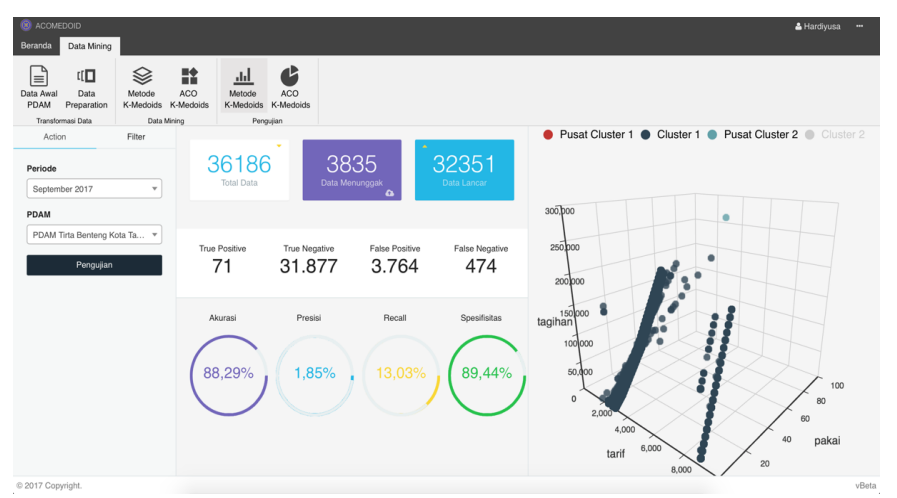

Gambar 5: Hasil pengujian metode $K$-Medoids
Pengujian pada metode ACOMedoids digunakan datalatih dan data aktual sama seperti dengan pengujian pada metode K-Medoids. Pengujian langsung menggunakan aplikasi dan terlihat pada Gambar 6 dan Tabel V menunjukkan hasil pengujian untuk masing-masing PDAM.

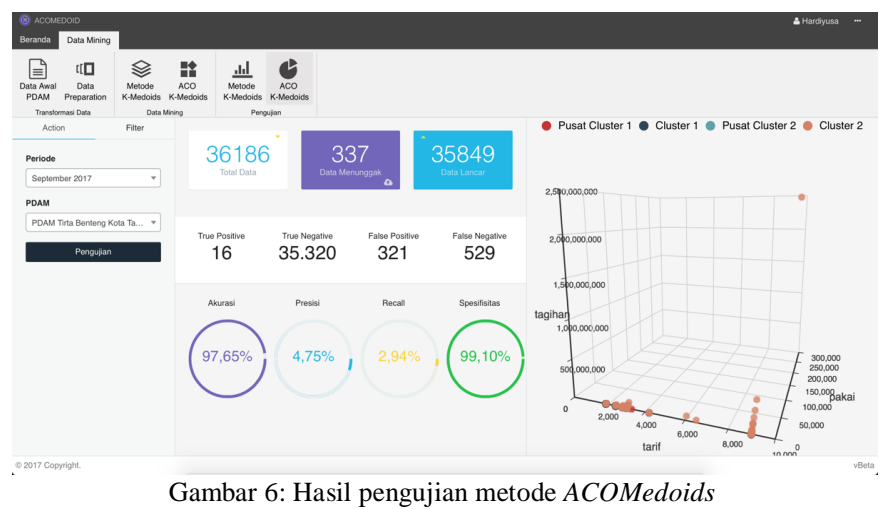

Tabel V terlihat nilai akurasi terus naik sesuai jumlah data latih yang digunakan semakin besar data latih, maka semakin besar tingkat akurasi yang didapatkan.

TABEL V

Hasil Pengujian AKuRasi Metode $K$-MEDOIDS DAN Metode ACOMEDOIDS

\begin{tabular}{|c|c|c|c|c|c|c|c|c|c|c|c|}
\hline \multirow{3}{*}{ No } & \multirow{3}{*}{ Nama PDAM } & \multicolumn{5}{|c|}{ K-Medoids } & \multicolumn{5}{|c|}{ ACOMedoids } \\
\hline & & \multicolumn{4}{|c|}{ confusion matrix } & \multirow{2}{*}{$\begin{array}{c}\text { Akurasi } \\
(\%)\end{array}$} & \multicolumn{4}{|c|}{ confusion matrix } & \multirow{2}{*}{$\begin{array}{c}\text { Akurasi } \\
(\%)\end{array}$} \\
\hline & & TP & $\mathbf{T P}$ & TP & TN & & TP & $\mathbf{T P}$ & TP & TN & \\
\hline 1 & $\begin{array}{l}\text { PDAM Kab. Timor Tengah } \\
\text { Utara }\end{array}$ & 497 & 897 & 324 & 2191 & 35,66 & 728 & 844 & 377 & 1960 & 40,21 \\
\hline 2 & PDAM Kab. Buru & 540 & 516 & 166 & 2813 & 26,17 & 1759 & 409 & 273 & 1594 & 53,73 \\
\hline 3 & PDAM Kota Pekanbaru & 886 & 6565 & 2516 & 2373 & 60,38 & 113 & 8465 & 616 & 3146 & 69,51 \\
\hline 4 & $\begin{array}{l}\text { PDAM Kab. Polewali } \\
\text { Mandar }\end{array}$ & 1161 & 7727 & 3038 & 3571 & 57,35 & 1121 & 7838 & 2927 & 3611 & 57,81 \\
\hline 5 & PDAM Kab. Klungkung & 212 & 24995 & 3305 & 1309 & 84,52 & 155 & 25959 & 2344 & 1366 & 87,56 \\
\hline 6 & PDAM Kota Tangerang & 71 & 31877 & 3764 & 474 & 88,29 & 16 & 35320 & 321 & 529 & 97,65 \\
\hline
\end{tabular}

Hardiyusa: Potensi Pelanggan Tunggakan PDAM ... 


\section{Perbandingan Metode K-Medoids dengan ACOMedoids}

Perbandingan dilakukan terhadap metode K-Medoids dengan metode ACOMedoids erhadap akurasi dari hasil pengujian dengan metode confusion matrix.

Akurasi merupakan persentase ketepatan record data yang diklasifikasikan secara benar setelah dilakukan pengujian pada hasil klasifikasi. Perbandingan akurasi hasil pengujian antara metode $K$-Medoids dengan metode ACOMedoids dapat dilihat pada Gambar 7. Pada Gambar 7 menunjukkan akurasi metode ACOMedoids terlihat lebih tinggi dan lebih baik dibandingkan metode $K$-Medoids, hal ini menunjukkan titik pusat cluster yang didapat dari hasil algorima ACO terbukti optimal dibandingkan dengan penentuan titik pusat cluster dengan menggunakan metode $K$-Medoids.

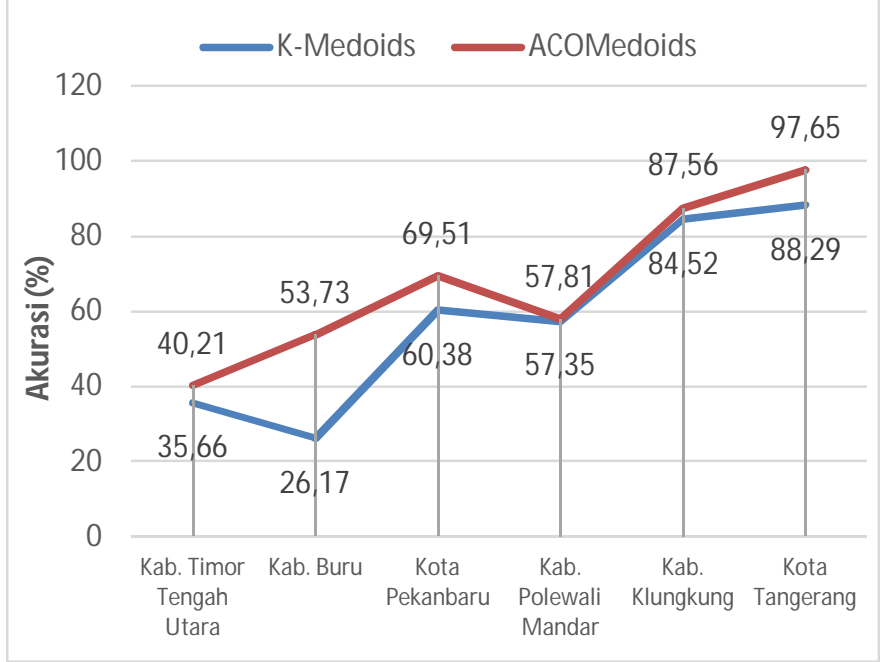

Gambar 7: Grafik perbandingan akurasi hasil pengujian

Nilai akurasi metode ACOMedoids selalu lebih tinggi dan lebih baik dibandingkan dengan metode $K$-Medoids, hal ini disebabkan oleh dalam penentuan titik cluster $K$-Medoids melakukan pemilihan secara acak dari data latih dan bergantung jumlah iterasi yang dilakukan semakin banyak iterasi memungkinkan mendapat titik cluster yang lebih baik tetapi itu akan membutuhkan waktu yang sangat lama. Sedangkan metode ACOMedoids dalam menentukan titik cluster menggunakan algoritma ACO yang mencari jarak terpendek dari setiap data latih, sehingga didapatkan fungsi minimal sebagai titik cluster. Metode ACOMedoids memerlukan waktu yang lebih lama pada saat proses algoritma ACO karena melibatkan semua data latih, tetapi tidak memerlukan jumlah iterasi yang banyak pada metode clustering K-Medoids berikutnya. Sehingga jika dalam efisiensi dan efektifitas dapat dikatanya metode ACOMedoids lebih baik dibandingkan K-Medoids. Nilai akurasi masingmasing PDAM terlihat bervariasi dan cenderung naik mengikuti jumlah data latih yang digunakan, semakin besar data latih, maka semakin besar tingkat akurasi yang didapatkan. Tetapi hal ini tidak dapat menjadi acuan karena data tagihan rekening PDAM Kab. Klungkung dan PDAM Kota Tangerang memiliki data rekening yang lebih bersih dibandingkan PDAM yang lain, jadi tingkat akurasi juga dipengaruhi oleh beberapa faktor selain jumlah data yaitu data rekening yang bersih tidak memiliki lebih dari 3 tunggakan dan kebijakan masing-masing PDAM dalam hal pelanggan aktif dan penerbitan rekening tagihan pelanggan.

\section{KESIMPULAN}

Metode $K$-Medoids dan ACOMedoids dapat menghasilkan kelompok serta jumlah data pelanggan yang memiliki potensi untuk menunggak tagihan air (pelanggan tunggakan) maupun tidak menunggak (pelanggan lancar) pada periode tagihan berjalan. Algortima ACO dapat menghasilkan titik pusat cluster yang optimal pada proses clustering metode $K$ Medoids. Metode ACOMedoids dapat menghasilkan tingkat akurasi yang tinggi dari perbandingan data hasil clustering dengan data tagihan aktual dari PDAM. Hal ini terlihat pada hasil akurasi yang selalu lebih baik dibandingkan dengan metode $K$-Medoids yaitu tertinggi mencapai akurasi $97,65 \%$ pada PDAM Tirta Benteng Kota Tangerang.

\section{REFERENSI}

[1] BPPSPAM. Buku Kinerja PDAM 2016. Jakarta: BPPSPAM, 2016.

[2] C. Laspidou, et all. "Exploring Patterns In Water Consumption By Clustering" Elsevier: Procedia Engineering 13th Computer Control for Water Industry Conference, CCWI, 2015, 119:1439-1446.

[3] S. Moedjiono, F. Fransisca and A. Kusdaryono. "Segmentation and Classification Customer Payment Behavior at Multimedia Service Provider Company with K-Means and C4.5 Algorithm” International Journal of Computer Networks and Communications Security, Vol. 4, No. 9:265-275, 2015.

[4] K. Dahiya, S. Bhatia, "Customer Churn Analysis in Telecom Industry" IEEE 4th International Conference on Reliability, Infocom Technologies and Optimization (ICRITO) (Trends and Future Directions), 2-4 Sept. 2015.

[5] A. J. Hamid and T. M. Ahmed. "Developing Prediction Model Of Loan Risk In Banks Using Data Mining" Machine Learning and Applications: An International Journal (MLAIJ), Vol.3, No.1, 2016.

[6] M. Sood and S. Bansal, "K-Medoids Clustering Technique using Bat Algorithm" International Journal of Advanced Research in Computer Science and Software Engineering, 2013, Vol.5, No.8:20-22.

[7] R. Hadi, I K. G. D. Putra dan I N. S. Kumara, "Penentuan Kompetensi Mahasiswa Dengan Algoritma Genetik Dan Metode Fuzzy C-Means", Majalah Ilmiah Teknologi Elektro, Vol. 15, No. 2, Juli - Desember 2016.

[8] P. Suwirmayanti, I K. G. D. Putra dan I N. S. Kumara, "Optimasi Pusat Cluster K-Prototype Dengan Algoritma Genetika", Majalah Ilmiah Teknologi Elektro, Vol. 13, No. 2, Juli - Desember 2014.

[9] M. Dorigo, L. M. Gambardella, “Ant Colony System: A Cooperative Learning Approach to the Traveling Salesman Problem", IEEE Transactions on Evolutionary Computation, 1:53-56, 1997.

[10] M. Dorigo, T. Stutzle, Ant Colony Optimization. London: A Bradford Book The MIT Press, 2004.

[11] J. Han, M. Kamber, Data mining: Concept and Techniques second edition. USA: Elsevier Inc, 2006.

[12] F. Gorunescu, Data mining Concepts, Models and Techniques. Romania: Springer-Verlag Berlin Heidelberg, 2011. 